\title{
Biomass crops can be used for biological disinfestation and remediation of soils and water
}

by James J. Stapleton and Gary S. Bañuelos

Many plants that are candidates for refining into biofuels also possess qualities that make them potentially useful for managing soilborne pests, reclaiming polluted soils, supplementing animal feed and other purposes. Phytoremediation with these plants may provide a practical and economical method for managing the movement of trace elements into water tables, surface- and tail-water runoff, and drainage effluent. Mustards (Brassicaceae) are of particular interest for biodiesel, and grasses (Gramineae) for bioethanol production. These plants, as well as others such as certain members of the onion family (Alliaceae), also possess properties that could make them effective natural biofumigants for soil. Some of these crops have high allelopathic activity and must be employed carefully in rotations to avoid damaging subsequent crops.

ecent interest in the production of Rbiofuels from agricultural feedstocks has resulted in considerable controversy. On one hand, biofuels offer partial relief from societal demand for petroleum, and their combustion products may contribute less to global climate change than fossil fuels. On the other hand, widespread production of biofuels from staple crops raises prices and may result in food scarcity. Also, increased cultivation of biomass can hasten degradation of environmental features, such as soil quality and water availability, and increase destruction of wildlands for conversion to cropping. As issues of biomass production are debated in California, the "value-added" sustainability of candidate feedstocks for biofuels must be considered.

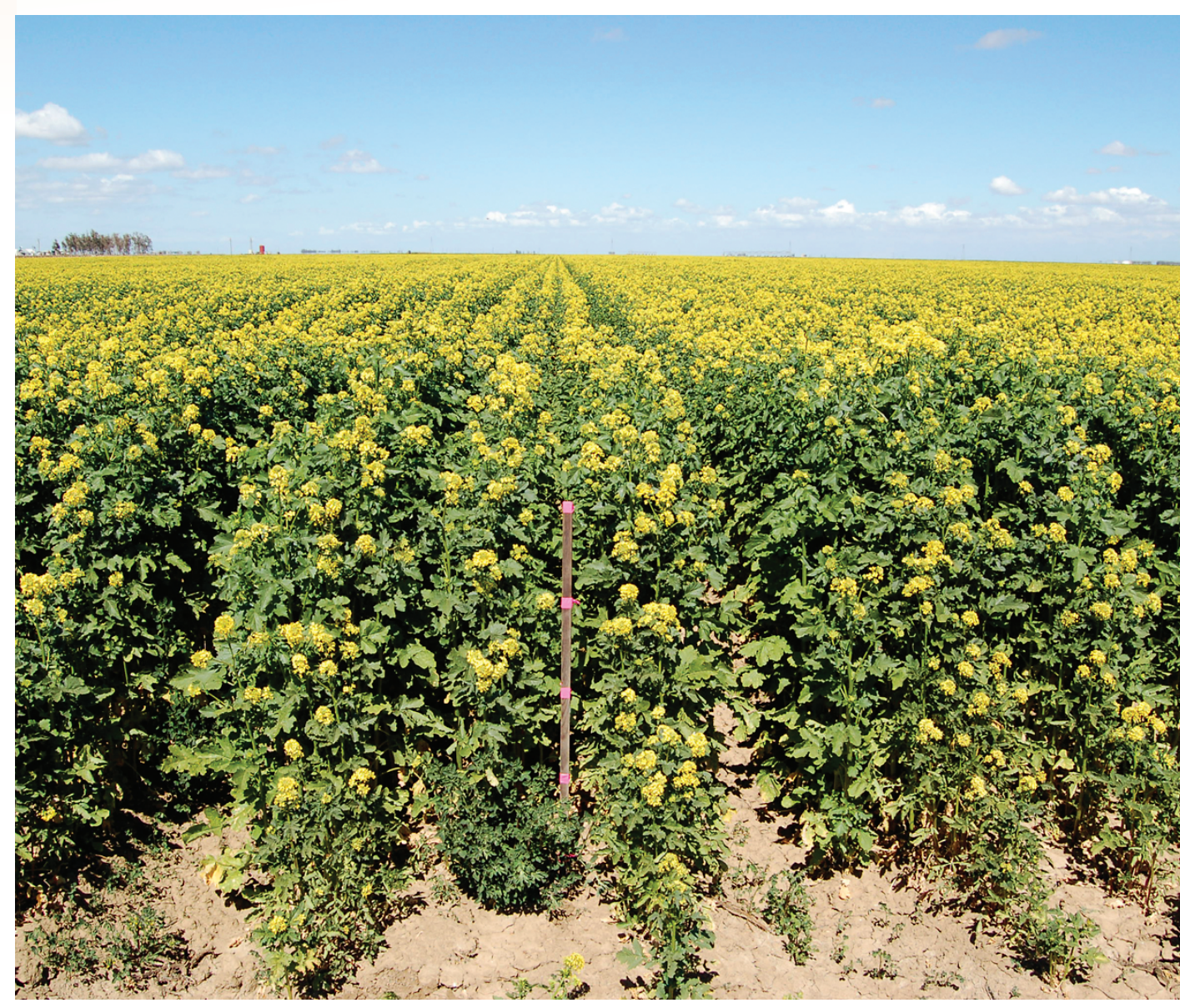

Plants in the mustard family (Brassicaceae), such as 'Ida Gold' at Red Rock Ranch near Five Points, are of particular interest for biodiesel production. Chemicals produced by these plants appear to have pesticidal activity that may also be useful for soil disinfestation.

Many plants that are currently or potentially useful as biomass crops for biofuel production also possess properties that may be exploited for other purposes, such as managing soilborne pests or reclaiming polluted soils (in addition to traditional uses such as soilbuilding and nutrient management). A number of candidate species for biofuel production are taxonomically grouped into two plant families: mustards (Brassicaceae), of particular interest for biodiesel, and grasses (Gramineae), of wide interest for bioethanol production.

Editor's note: An upcoming 2009 edition of California Agriculture will feature a special collection on biofuels research and policy.
Both have a long history of scientific study and characterization of their various bioactive properties.

Devising processes that take advantage of not only their primary crop value but also their biofumigation, phytoremediation or other properties, may optimize the usefulness of these "multitasking" biomass plants. For pest disinfestation, simply incorporating raw or residual plant materials into soil may be sufficient. The amended soil, however, may need a sealing cover or heating in order to derive maximum benefit. Conversely, phytoremediation of soils requires the long-term presence of growing plants to actively scavenge unwanted trace elements or compounds from the soil. Plant materials enriched with trace elements must then be collected and pro- 


\section{Glossary}

Allelopathy: Deleterious effects of chemical constituents of one plant species on (an)other species.

Bioactivity: Effect on, or response of, an organism or living tissue upon exposure to a substance or agent.

Biofuel (biodiesel, bioethanol), bioenergy: Alternative fuel/energy produced from biological sources such as plants, animal oils or fermentation.

Biofumigation, soil: Intentionally using bioactive plants and other organic materials to aid in reducing populations of plant pests in soil.

Biomass crop: Plants grown for conversion into fuel or other nonfood commodities.

Disinfestation, soil: Reduction or elimination of harmful organisms from soil by physical, chemical and/or biological means.

Phytoremediation: Use of plants/trees to manage high levels of unwanted trace elements or compounds by accumulation, volatilization or stabilization.

Phytotoxicity: Quality or extent of producing deleterious effects on plants by means of a toxin or poisonous substance.

cessed during the biofuel conversion process, and reutilized if possible.

\section{Biofumigation of soils}

Since ancient agriculturists began managing crops seasonally, plant residues left in the field after harvest have offered both benefits and challenges. While beneficially contributing organic material and nutrients to the soil after decomposition, or remaining on the soil surface as moisture-conserving mulch, plant residues also sometimes harbor destructive pests and disease-causing organisms ready to attack the next crop. This is especially harmful if the susceptible plants are grown in a monoculture over and over again in a particular field or region.

Growers learned that following a particular crop with a taxonomically different crop (one not susceptible to the same

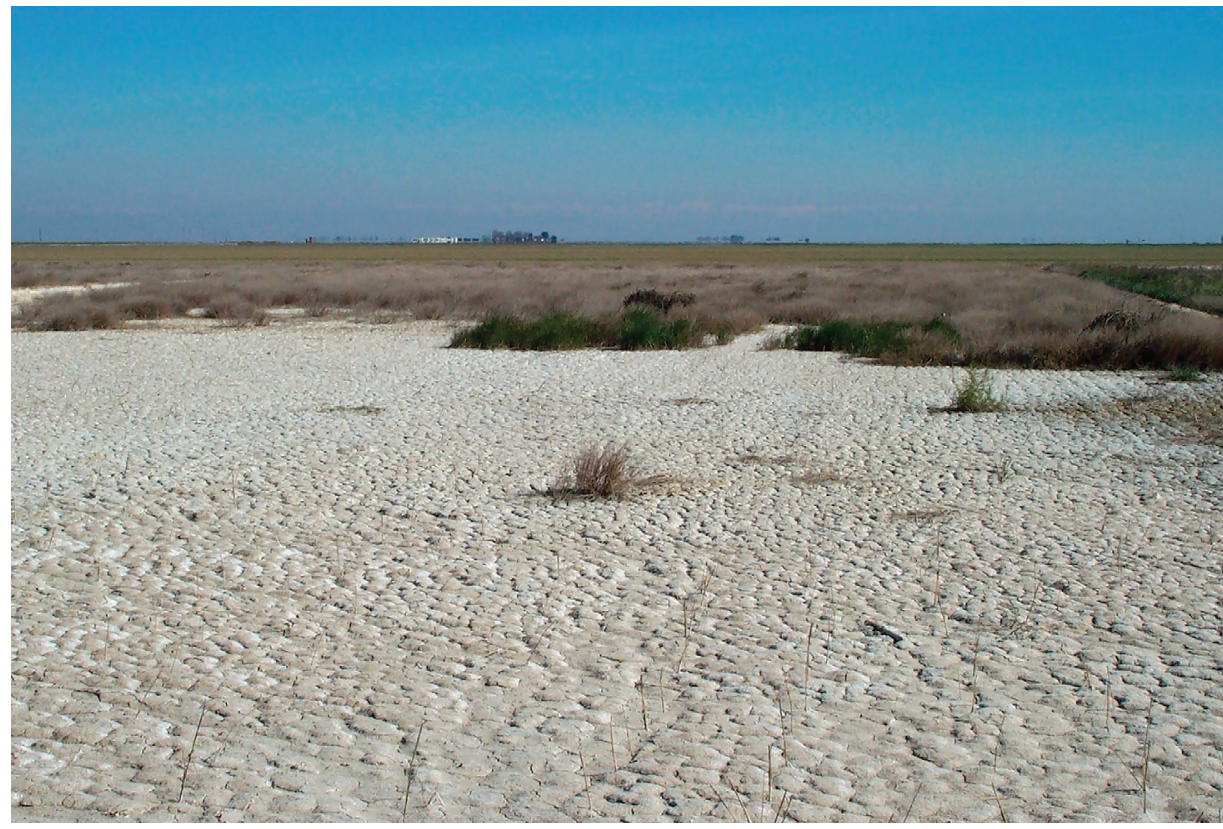

At Red Rock Ranch in the west-central San Joaquin Valley, UC and USDA-ARS researchers are studying the use of biomass crops to remediate residual salts, including those containing selenium. Some "multitasking" biomass crops may function as feedstocks for biofuels as well as help manage soilborne pests or reclaim polluted soils.

pests) often eliminates carry over pest problems and sometimes even results in unexpected growth and yield increases. However, certain crops were also found to inhibit the growth of subsequent crops. These observations form the basis of the modern agricultural strategy of crop rotation, or sequencing, in which thoughtful crop scheduling - in terms of both biology and economics - can provide maximum advantages for the cropping continuum. The commercialization of potent soil fumigation chemicals from the 1950s to the 1970s diminished the apparent value of crop rotation as a pest control tactic. However, after environmental and safety problems became associated with many of the soil pesticides, interest in crop rotation was sparked anew.

In recent years, interest has grown in the cultivation of biomass crops for liquid fuel production (Jenkins et al. 2009), although serious global concerns have been raised regarding the sustainability of switching from food production crops to biofuel feedstock cultivation (Gomez et al. 2008). Interestingly, many of the plant taxa being used or tested, including members of the grass and mustard families, also possess bioactive properties that make them useful as biofumigation residues.
Brassica spp. Much of current interest in the Brassicaceae revolves around a constituent class of nitrogen- and sulfur-containing compounds called glucosinolates. These compounds, which are responsible for the spicy-hot flavor in mustards and radishes, have been widely studied as possible anticancer agents as well as for antimicrobial properties (Rosa et al. 1997). Upon hydrolysis, glucosinolates break down into a number of bioactive compounds, including isothiocyanates, some of which are synthetically manufactured for use as soil pesticides (Morra and Kirkegaard 2002). The term "biofumigation," first coined to describe the particular use of Brassicaceous cover crops or soil amendments for isothiocyanate release, has become associated with the more general practice of intentionally using bioactive plants and other organic residues to aid in soil disinfestation (Stapleton et al. 2000).

Apart from the glucosinolates, studies have demonstrated that the pesticidal activity of Brassica spp. is likely due to mechanisms other than, or in addition to, isothiocyanate release following glucosinolate hydrolysis. Much of the biofumigation research has focused on the role of isothiocyanates as being primarily 


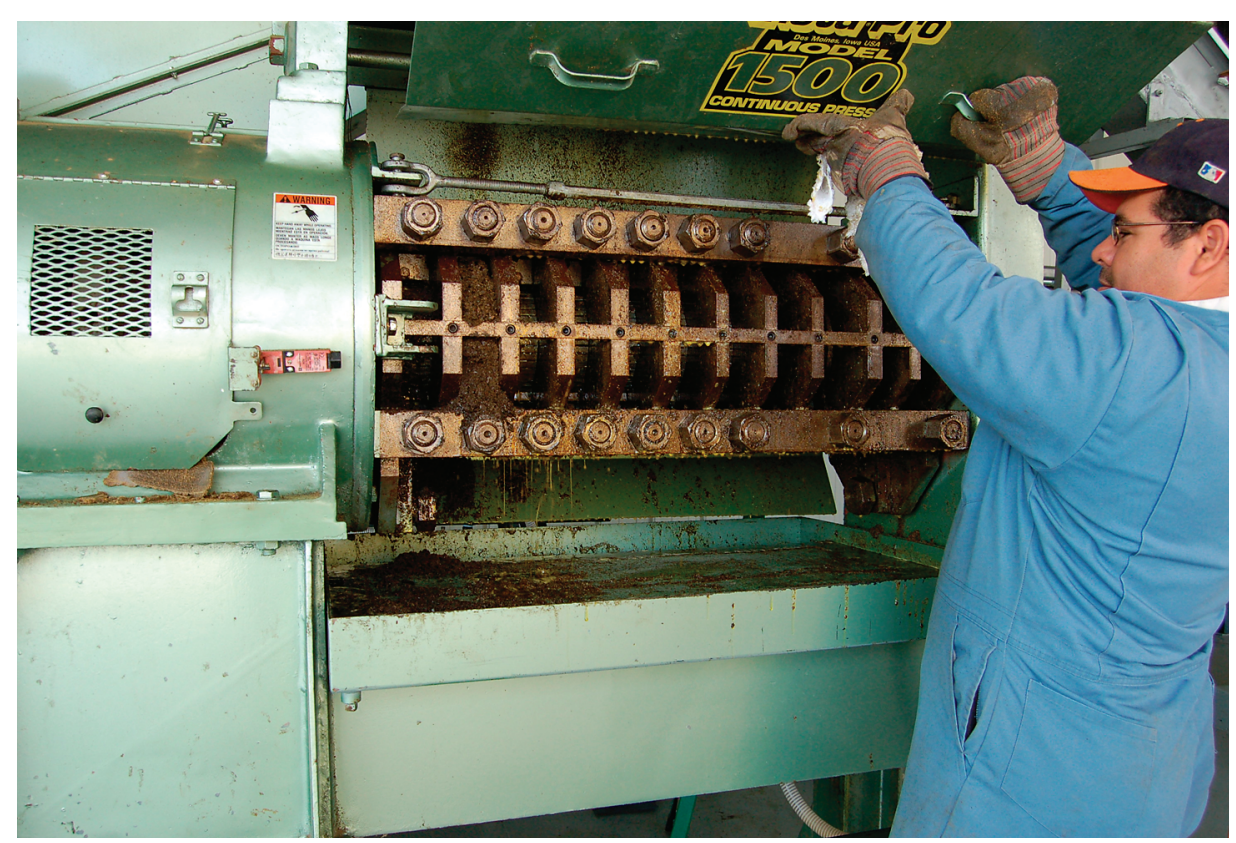

German Perez uses a press to extract oil from mustard and canola seeds, which were irrigated with water high in salt, boron and selenium. Under experimental conditions, the press can process up to a ton of canola seed per hour with an oil-extraction efficiency of nearly $90 \%$.

responsible for the pesticidal effects. But additional chemical compounds arising from nonglucosinolate pathways - including aldehydes, acids and other sulfur- and nitrogen-containing compounds released during plant growth or decomposition in soil also have significant pesticidal activity (Kelly and Baker 1990; Gamliel and Stapleton 1993; Bending and Lincoln 1999). Furthermore, besides chemical activity, alterations in microbial activity (Gamliel and Stapleton 1993) that are deleterious to pest organisms (Hao et al. 2003) have also been associated with Brassica-mediated soil disinfestation.

In California, published results on biofumigation with Brassica spp. range from spectacular to insignificant. Experimental work in the Salinas Valley reported that broccoli (B. oleracea var. italica) rotations were effective in controlling certain soilborne fungal pathogens, such as Verticillium and Sclerotinia, in vegetable crop rotations (Koike and Subbarao 2000; Hao et al. 2003). In contrast, cropping and subsequent soil incorporation of rape/canola (B. napus) and certain mustards (B. juncea and Sinapis alba) had no significant effects on the soilborne pests of processing tomatoes in the Sacramento Valley (Hartz et al. 2005).

Several studies in California have demonstrated that covering and heat- ing soil containing Brassica residues can produce deleterious effects on soilborne fungi and nematodes far exceeding those where the residues were simply incorporated into natural field soil (Ramirez-Villapudua and Munnecke 1986; Gamliel and Stapleton 1993; Stapleton and Duncan 1998; Ploeg and Stapleton 2001). During plant residue decomposition, concentrations of volatile chemical compounds in the soil tend to increase with increasing temperature (fig. 1). This is important because toxic effects are a function of the toxicant concentration multiplied by the duration of pounds from decomposing crop residues generally occurs within a few days after their incorporation in moist soil (fig. 2). Manipulation of the system via soil covers and/or heating to maximize biofumigant concentrations can be the difference between the effective and ineffective management of pests.

Grasses. Members of the grass family (Gramineae) also produce a rich diversity of bioactive chemical compounds, including phenolics, glycosides, benzoxazinones and amino acids. Although many are primarily known for their allelopathic activity against other plants (Putnam and DeFrank 1983), they may also possess properties deleterious to a broad range of fungi, bacteria, nematodes and insects exposure. The liberation of volatile com-

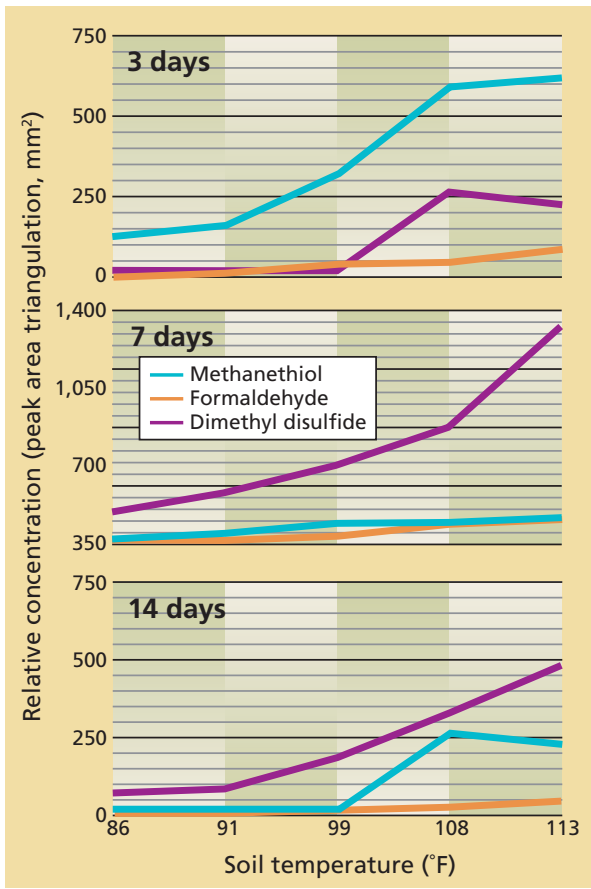

Fig. 1. Effects of soil temperature and time on relative concentration dynamics of three volatile chemicals in soil during a laboratory study. The chemicals are nonglucosinolatederived decomposition products of cabbage plant residues, which were incorporated in soil microcosms 3, 7 and 14 days prior to headspace sampling and analysis by gas chromatography (adapted from Gamliel and Stapleton 1993).

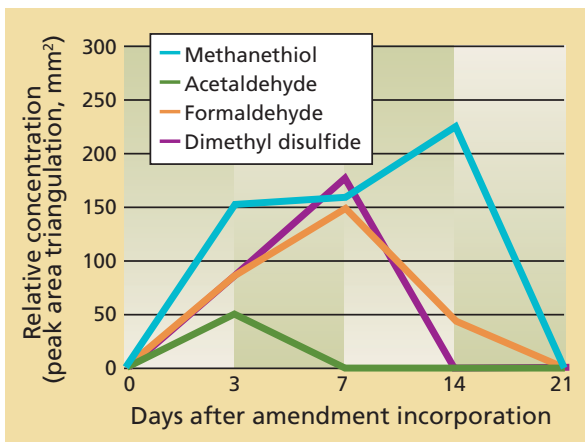

Fig. 2. Relative soil atmosphere concentration dynamics of four volatile chemical compounds produced during cabbage plant decomposition in a field study. The compounds, not derived from glucosinolate hydrolysis, were liberated from plant residues incorporated at day ' 0 ' in moist soil, which was then subjected to diurnal solar heating (solarization) prior to headspace sampling and analysis by gas chromatography (adapted from Gamliel and Stapleton 1993).

in soil. For example, residues of several Gramineous crops of agronomic importance, including cultivars of barley (Hordeum vulgare), wheat (Triticum aestivum), triticale (X Triticosecale) and oats (Avena sativa), all demonstrated significant, deleterious effects on soilborne nematodes during their decomposition 
in soil. Phytotoxicity was evident in many test plants when they were subsequently established in the soil shortly after amendment with the residues (Stapleton 2006).

A similar phytotoxic effect was even more pronounced when field and greenhouse studies were conducted using sudex, a hybrid of sorghum and sudangrass (Sorghum bicolor $\times$ S. sudanense), as a cover crop. Severe allelopathic effects occurred on subsequently planted tomato, broccoli and lettuce transplants, unless a waiting period of at least 6 weeks was observed between the incorporation of sudex residues in soil and planting of the following crop (Summers et al. 2009; see page 35).

Garlic and onions. Yet another group of bioactive plants are those in the onion family (Alliaceae). Garlic and onion, especially, have been known for their bioactive properties since ancient times. Feasibility studies examined the decomposition of garlic and onion residues in moist soil, as related to the seed inactivation of four important agricultural weeds: black nightshade (Solanum nigrum), common purslane (Portulaca oleracea), London rocket (Sisymbrium irio) and barnyardgrass (Echinochloa crus-galli). The inhibitory and herbicidal effects of the Alliaceous residues were generally mild or inconsistent when tested at soil temperatures of $73.4^{\circ} \mathrm{F}$ $\left(23^{\circ} \mathrm{C}\right)$. However, at $102.2^{\circ} \mathrm{F}\left(39^{\circ} \mathrm{C}\right)$, which by itself was mildly inhibitory to weed seed germination, the activity of the decomposing residues was far more potent (Mallek et al. 2007).

Rotational crops as pesticides. Today, there is great interest in developing rotational crop cultivars that can act as natural pesticides, and also in identifying, purifying and synthesizing bioactive compounds. The question of biocidal or inhibitory activity stemming from soil amendment with crop residues is one of great importance when considering crop sequencing. The desired result is to produce a biofumigation effect on targeted pests without harming or retarding the following crop. The old adage "the dose is the poison" comes into play here, and rotation crops with high allelopathic activity must be incorporated sparingly, or soil must be leached or fallowed between subsequent crops.

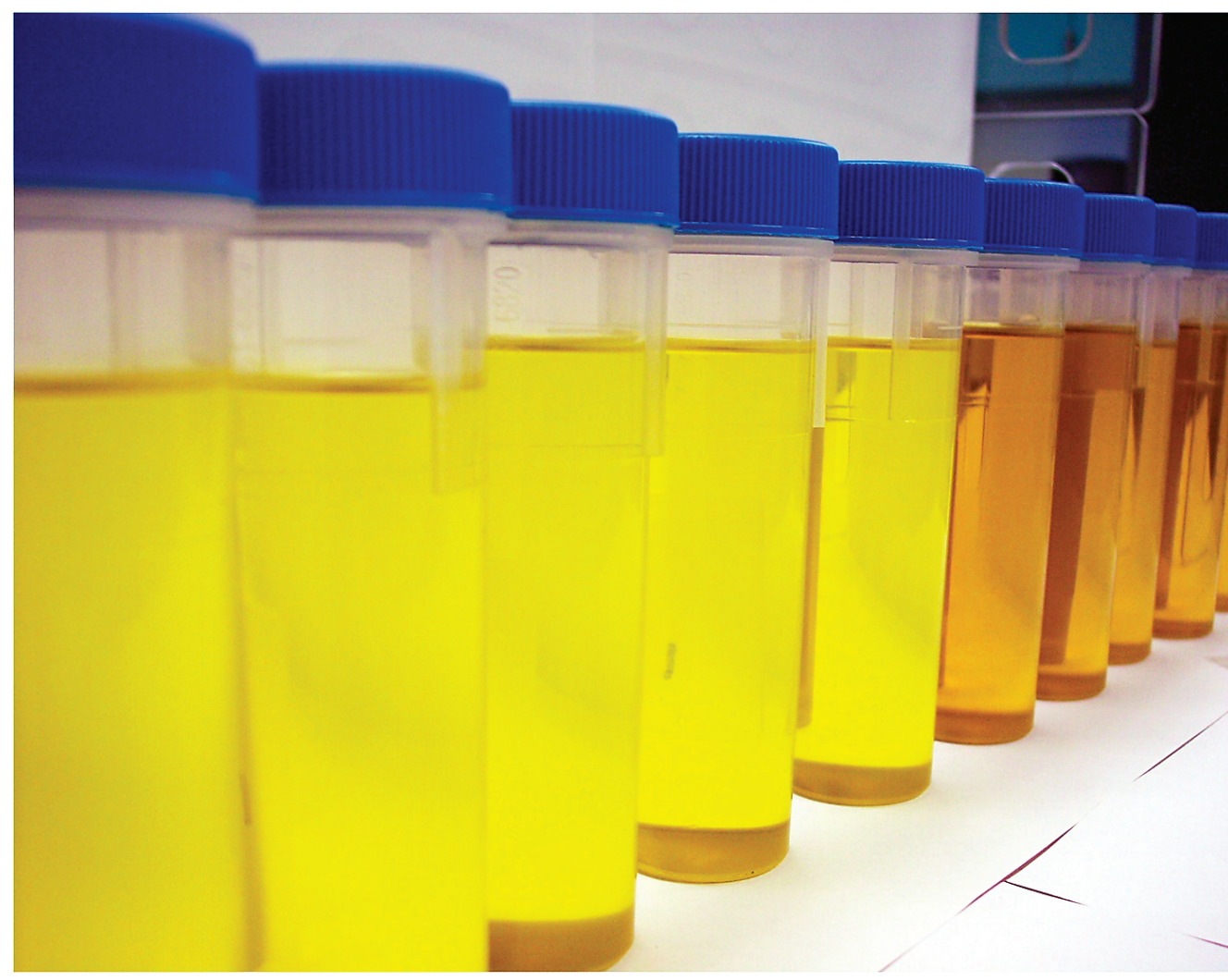

Freshly extracted canola (left) and mustard oils (right) from Brassicaceous plants can be grown for the phytomanagement of soluble selenium in the soil.

Many plants that could potentially produce biofumigation effects during their decomposition in soil have activity that is mild, inconsistent or both. Combining incorporation with a soil sealant such as plastic film or a water layer may intensify the pesticidal effect, especially if the plastic film is applied to moist soil during warm weather for solarization (Ramirez-Villapudua and Munnecke 1986; Gamliel and Stapleton 1993; Stapleton and Duncan 1998; Ploeg and Stapleton 2001).

The soil environment is complex and not clearly understood. Biofumigation, as with other approaches to the biological control of soilborne pests, cannot be expected to perform in every field or geographic area uniformly or consistently. Factors affecting the performance of organic amendments used for soil disinfestation include soil type, texture, chemical composition, temperature and moisture content, composition of native soil microflora and cropping history (Stapleton et al. 2000; Stapleton 2006; Mallek et al. 2007).

Apart from the plant taxa mentioned here, many others possess properties, metabolites and decomposition products that may be useful for managing soilborne plant pests. Additional studies will be needed to optimize their rotation with the high-value specialty crops that are important and unique to California's agricultural landscape. Scientists and growers will be looking carefully at crop sequencing, with an eye toward employing specific crops as soil disinfestants that can provide additional usefulness and sustainability to their cultivation.

\section{Phytoremediation of soils and water}

Excess trace elements such as arsenic (As), boron (B) and selenium (Se) can cause significant soil and water pollution. "Phytoremediation" uses accumulator plants or tree species with deep rooting systems to scavenge and collect mobile trace elements residing in contaminated soils. This plant-based technology may provide a practical and economical method to slowly manage the movement of trace elements into water tables, surface- and tail-water runoff, and drainage effluent. For example, in the central San Joaquin Valley's 
west side, phytoremediation has been tested by several growers for managing soluble selenium by using cropping systems in conjunction with microbial activity to extract, accumulate, volatilize and stabilize the offending pollutant.

Managing selenium. Although field research on selenium phytoremediation is still in the nascent stage (Bañuelos 2000), intensive and long-term field studies are key to developing sound strategies for detoxifying soils and sediments. Growing crops on a sustained basis to manage soluble selenium requires knowledge of a wide range of site-specific factors, including the: (1) impact of high soil salinity when coupled with phytotoxic concentrations of additional elements, such as boron or arsenic; (2) presence of competitive ions, such as sulfate $\left(\mathrm{SO}_{4}{ }^{2-}\right)$, which affect selenium uptake and volatilization by plants; (3) utilization of groundwater and drainage water management strategies under saline conditions; (4) consumption and infestation of phytoremediation crops by wildlife and pests; (5) development of sustainable cropping systems; (6) production of viable products from crops used for phytoremediation; and (7) acceptance of phytoremediation as a management technology by the public and growers in regions known to have selenium contamination.

Crop selection is an important factor for successful field management of selenium. Bioremediation crops should be compatible in rotations with other agronomic crops, such as cotton, wheat,

Since ancient agriculturists began managing crops seasonally, plant residues left in the field after harvest have offered both benefits and challenges.

tomatoes and sugarbeets, which are typically grown in the saline soils of central California (Shennan et al. 1995), or in rotation with other crops used in phytoremediation (Bañuelos 2002). For the last 2 decades, researchers from the University of California, California State University (CSU) and U.S. Department of Agriculture Agricultural Research Service (USDA-ARS) have studied the use of selenium-tainted agricultural drainage water as an alternative source of irrigation water in central California (Suyama et al. 2007). Two multifaceted Brassica crops are now under serious consideration for water reuse strategies where selenium is present: canola and mustard (B. juncea) (Bañuelos et al. 2000; Bañuelos 2006). On-farm experiments near Five Points and Firebaugh successfully demonstrated that the two species accumulated and volatilized selenium from polluted drainage water reapplied for irrigation, hence minimizing the buildup of soluble selenium in the soil (Bañuelos 2002; Zayed et al. 2000).

Canola and mustard. In order for the Brassica species to play an important role in remediation of California soils, viable economic uses must be developed for their harvested plant products. Worldwide, canola and mustard are mainly grown for their seed, which has a high oil content, 35\% to 40\% (Carr 1995). Canola and mustard oils also have high energy content per unit weight and are two of the most efficient sources of bioenergy in terms of British thermal units (BTUs) per acre planted. These attributes have led to interest in the adoption of canola and mustard oils as sources of biodiesel fuel (McDonnell et al. 2000).

Since 2002, USDA-ARS scientists, in cooperation with Red Rock Ranch in Five Points, have been investigating the production of biodiesel from oil extracted from canola and mustard plants irrigated with selenium-tainted water. Initial efforts have resulted in the capability to process up to 1 ton of canola seed per hour, using an Insta Pro 1500 Oil Press and a 2000 RC Extruder (Insta Pro International, Des Moines, IA), with an ideal oil extraction efficiency of almost $90 \%$ under controlled experimental conditions. Seed yields were estimated as high as 1.7 tons per acre when derived from hand-sampling a multitude of 10.8-square-foot (1-square-meter) microplots prior to major harvest. In general, about 1 ton of seed per acre was mechanically harvested from canola grown with soil and water containing an average sulfate-dominated salinity of 7 deciSiemens per meter $(\mathrm{dS} / \mathrm{m}), 150$ parts per billion (ppb) soluble selenium and 5 parts per million $(\mathrm{ppm}=$ milligrams per kilogram) soluble boron. From seed yields determined under field conditions, an optimal production of 100 gallons (380 liters) of $100 \%$ biodiesel (BD100) made from canola and mustard oil, or 500 gallons (1,900 liters) of BD20 biodiesel (a mixture of $20 \%$ vegetable oil and $80 \%$ petrodiesel) per acre could be achieved.

Selenium-enriched seed meal. Another potential byproduct from Brassica phytoremediation crops is the residual, selenium-enriched seed meal remaining after oil extraction. Canola meal is one of the most widely traded protein ingredients in the world; its use in animal feed rivals soybean meal because of its high nutritional quality in terms of fiber, protein and fat. In phytoremediation experiments on the San Joaquin Valley's west side, the selenium concentration in residual canola meal was almost 2 ppm of dry matter (Bañuelos 2006).

The benefit of selenium in canola meal is that it is a component of the animal enzyme glutathione peroxidase, an antioxidant capable of reducing the celldamaging free radicals produced during metabolism or from oxidant stress (Gladyshev and Hatfield 1999). Based upon these nutritional characteristics, collaborative feed trials with Holstein and Jersey dairy cows are in progress at CSU Fresno, whereby the seleniumenriched canola seed meal (at 2 ppm of dry matter) is provided as a selenium source instead of the more expensive selenized yeast or the inorganic form of selenium that would normally be added, as needed, to daily feed rations.

Similarly, in earlier research Bañuelos and Mayland (2000) improved the selenium status of animals by carefully mixing selenium-rich vegetative canola plant material with other animal feedstuffs. An organic source of selenium may be more bioavailable than inorganic sources (Muñiz-Naveiro et al. 2006), but selenium absorption by animals will always depend on the animal species, duration of feeding, composition of diet and ruminal microbial population (Koenig et al. 1997).

Animal requirements for selenium are generally low, between 0.1 and 0.3 ppm of the diet dry matter (Mayland 
1994), so it is important that selenium concentrations in organic sources of selenium, such as canola seed meal, be constantly monitored to ensure that excessive selenium levels do not occur. Irrespective of the selenium source used to maintain healthy dairy production, excessive selenium provided to animals in synthetic or inorganic forms is not only potentially toxic to the animals but also may increase the environmental burden of selenium cycled back into soil and water from animal manure. The incorporation of selenium-enriched canola seed meal in mixed animal diets can provide growers in high-selenium regions with an additional and valuable use for otherwise-discarded seed material after oil has been extracted. In contrast to canola, mustard seed meal after oil extraction tends to contain high concentrations of glucosinolates (approximately 300 ppm in mustard com- pared to $21 \mathrm{ppm}$ in canola), which is too high to be used in animal feed rations. Glucosinolates break down into toxic aglucones, and their bitter taste also results in reduced feed intake.

\section{Biomass crop sustainability}

The future extent, scope, sustainability and economics of biomass crop production, particularly with respect to biofuel feedstocks in California, cannot be predicted. Regardless, the coupling of biofumigation, phytoremediation, animal feed enrichment and other uses, along with primary commodity harvesting, may provide California growers with unique opportunities to increase the environmental and economic sustainability of these cropping systems. These and other value-added benefits should be identified, tested, incorporated and utilized in the widest possible range of crop taxa for maximum benefit and flexibility within cropping sequences. The early results reviewed here with certain cultivated members of the Brassicaceae, Gramineae and Alliaceae plant families can provide opportunities for additional work.

J.J. Stapleton is Integrated Pest Management Plant Pathologist and Coordinator, Natural Resources Program, UC Statewide IPM Program, UC Kearney Agricultural Center, Parlier; and G.S. Bañuelos is Research Plant/Soil Scientist, USDA-ARS, San Joaquin Valley Agricultural Sciences Center, Parlier. Author Stapleton gratefully acknowledges UC IPM Competitive Research Grant and USDA Smith-Lever Implementation Grant funds for partial support of the described studies. Author Bañuelos and USDA-ARS acknowledge the continued applied support of John Diener of Red Rock Ranch, and the financial support provided by the California State University Agricultural Research Initiative and Department of Water ResourcesProposition 204.

\section{References}

Bañuelos GS. 2000. Factors influencing field phytoremediation of selenium-laden soils. In: Terry N, Bañuelos GS (eds.). Phytoremediation of Contaminated Soil and Water. Boca Raton, FL: CRC Pr. p 41-59.

Bañuelos GS. 2002. Irrigation of broccoli and canola with boron and selenium-laden effluent. Environ Qual 31:1802-8

Bañuelos GS. 2006. Phyto-products may be essential for sustainability and implementation of phytoremediation. Environ Pollut 144:19-23.

Bañuelos GS, Mayland HF. 2000. Absorption and distribution of selenium in animals consuming canola grown for selenium phytoremediation. Ecotoxicol Environ Saf 46:322-8.

Bañuelos GS, Zambruski S, Mackey B. 2000. Phytoextraction of selenium from soils irrigated with Se-laden effluent. Plant Soil 224:251-8.

Bending GD, Lincoln SD. 1999. Characterisation of volatile sulphur-containing compounds produced during decomposition of Brassica juncea tissues in soil. Soil Biol Biochem 31:695-703.

Carr RA. 1995. Processing the seed and oil. In: Kimber D, McGregor D (eds.). Brassica Oil Seeds - Production and Utilization. Oxon, UK: CAB Int. p 267-90.

Gamliel A, Stapleton JJ. 1993. Characterization of antifungal volatile compounds evolved from solarized soil amended with cabbage residues. Phytopath 83:899-905.

Gladyshev V, Hatfield D. 1999. Selenocysteinecontaining proteins in mammals. Biomed Sci 6:151-60.

Gomez LD, Steele-King CG, McQueen-Mason SJ. 2008. Sustainable liquid biofuels from biomass: The writings on the walls. New Phytol 178(3):473-85.

Hao J, Subbarao KV, Koike ST. 2003. Effects of broccoli rotation on lettuce drop caused by Sclerotinia minor on the population density of sclerotia in soil. Plant Dis 87:159-66.
Hartz TK, Johnstone PR, Miyao EM, Davis RM. 2005 Mustard crops ineffective in soil-borne disease suppression or processing tomato yield improvement. HortSci 40:2016-9.

Jenkins BM, Williams RB, Gildart MC, et al. 2009. California biomass resources, potentials, logistics and current uses. Cal Ag. In press.

Kelly DP, Baker SC. 1990. The organosulphur cycle: Aerobic and anaerobic processes leading to turnover of $\mathrm{C}_{1}$-sulphur compounds. FEMS Microbiol Rev 87:241-6.

Koenig KM, Rode LM, Cohen RDH, Buckley WT. 1997. Effects of diet and chemical form of selenium on selenium metabolism in sheep. Can J Anim Sci 75:817-27.

Koike ST, Subbarao KM. 2000. Broccoli residues can control Verticillium wilt of cauliflower. Cal Ag 54(3):30-3.

Mallek SB, Prather TS, Stapleton JJ. 2007. Interaction effects of Allium spp. residues, concentrations and soil temperature on seed germination of four weedy plant species. Appl Soil Ecol 37:233-9.

Mayland HF. 1994. Selenium in plant and animal nutrition. In: Frankenberger Jr WT, Benson S (eds.). Selenium in the Environment. New York: Marcel Dekker. p 29-46.

McDonnell KP, Ward SM, McNulty PB, Howard-Hildige R. 2000. Results of engine and vehicle testing of semirefined rapeseed oil. Trans ASAE 43:1309-16.

Morra MJ, Kirkegaard JA. 2002. Isothiocyanate release from soil-incorporated Brassica tissues. Soil Biol Biochem 34:1683-90.

Muñiz-Naveiro Ó, Domínguez-González R, BermejoBarrera A, et al. 2006. Study of the bioavailability of selenium in cows' milk after a supplementation of cow feed with different forms of selenium. Anal Bioanal Chem 385:189-96.

Ploeg AT, Stapleton JJ. 2001. Greenhouse studies on the effect of time, temperature, and broccoli soil amendment on the infestation of melon plants by Meloidogyne incognita and M. javanica. Nematol 3:855-62.
Putnam AR, DeFrank J. 1983. Use of phytotoxic plant residues for selective weed control. Crop Prot 2:173-81.

Ramirez-Villapudua J, Munnecke DM. 1986. Solar heating and amendments control cabbage yellows Cal Ag 40(5-6):11-3.

Rosa EAS, Heaney RK, Fenwick GR, Portas CAM 1997. Glucosinolates in crop plants. Hortic Rev 19:99-215.

Shennan C, Grattan SR, May DM, et al. 1995. Feasibility of cyclic reuse of saline drainage in a tomato cotton rotation. J Environ Qual 24:476-86.

Stapleton JJ. 2006. Biocidal and allelopathic properties of gramineous crop residue amendments as influenced by soil temperature. In: Proc Calif Conf Biologic Contr V. p 179-81.

Stapleton JJ, Duncan RA. 1998. Soil disinfestation with cruciferous amendments and sublethal heating: Effects on Meloidogyne incognita, Sclerotium rolfsii and Pythium ultimum. Plant Pathol 47:737-42.

Stapleton JJ, Elmore CL, DeVay JE. 2000. Solarization and biofumigation help disinfest soil. Cal Ag 54(6):42-5.

Summers CG, Mitchell JP, Prather TS, Stapleton JJ. 2009. Sudex cover crops can kill and stunt subsequent tomato, lettuce and broccoli transplants through allelopathy. Cal Ag 63:35-40

Suyama H, Benes SE, Robinson PH, et al. 2007 Biomass yield and nutritional quality of forage species under long-term irrigation with saline-sodic drainage water: Field evaluation. Anim Feed Sci Tech 135:329-45.

Zayed A, Pilon-Smits E, de Souza M, et al. 2000 Remediation of selenium polluted soils and waters by phytovolatilization. In: Terry N, Bañuelos GS (eds.) Phytoremediation of Contaminated Soil and Water. Boca Raton, FL: CRC Pr. p 61-83. 